\title{
EKOWISATA TERINTEGRASI SITUS KAPAL TENGGELAM DI TIDORE KEPULAUAN, MALUKU UTARA
}

\section{INTEGRATED SHIPWRECK ECO-TOURISM IN TIDORE ISLANDS, NORTH MOLLUCAS}

\author{
Guntur Adhi Rahmawan', Nia Naelul Hasanah Ridwan1, Ulung Jantama Wisha1, Ilham ${ }^{1}$, \\ Wisnu Arya Gemilang1, Fitria Wahyu Andriani' ${ }^{2}$, Agus Sudaryadi ${ }^{3}$, \& Irwansyah $^{4}$ \\ ${ }^{1}$ Loka Riset Sumber Daya dan Kerentanan Pesisir, Kementerian Kelautan dan Perikanan \\ ${ }^{2}$ Pelabuhan Perikanan Samudera Bungus, Kementerian Kelautan dan Perikanan \\ ${ }^{3}$ Balai Pelestarian Cagar Budaya Jambi, Kementerian Pendidikan, Kebudayaan, Riset dan Teknologi \\ ${ }^{4}$ Balai Pelestarian Cagar Budaya Maluku Utara, Kementerian Pendidikan, Kebudayaan, Riset dan Teknologi \\ e-mail : guntura06@gmail.com
}

Diterima tanggal: 30 Juli 2021 ; diterima setelah perbaikan: 04 November 2021 ; Disetujui tanggal: 15 November 2021

\begin{abstract}
ABSTRAK
Kota Tidore Kepulauan mempunyai sejarah penting dibuktikan dengan adanya peninggalan historis dan arkeologis di darat maupun di bawah air. Ekowisata terintegrasi situs kapal tenggelam dapat dikembangkan dengan konsep wisata sejarah maritim dan arkelogi bawah air yang bertanggungjawab terhadap kelestarian lingkungan perairan, memperhatikan keutuhan budaya setempat, dan memberi manfaat secara ekonomi sehingga dapat meningkatkan pendapatan daerah. Tujuan penelitian adalah untuk mengetahui keberadaan situs kapal tenggelam beserta Benda Muatan Kapal Tenggelam (BMKT) yang dikandungnya, inventarisasi tempat bersejarah di Tidore, serta menilai kesesuaian lingkungan perairan untuk pengembangan ekowisata terintegrasi situs kapal tenggelam di Tidore. Survei arkeologi maritim dilakukan melalui penyelaman SCUBA untuk observasi situs dan mencari BMKT, pemetaan batimetri, dan observasi biota laut. Analisis artefaktual dilakukan untuk mengetahui jenis, umur, tempat asal artefak, dan konteks sejarah maritim. Analisis spasial untuk melihat posisi keletakan situs bawah air di antara tempat bersejarah dilakukan untuk pengembangan Heritage-Trail. Penilaian kualitas air disesuaikan dengan Peraturan Pemerintah No. 22 Tahun 2021 tentang Penyelenggaraan Perlindungan dan Pengelolaan Lingkungan Hidup Lampiran VIII. Berdasarkan hasil survei, ditemukan 2 (dua) situs bawah air yaitu Soasio di kedalaman 10-20m dan Tongowai di kedalaman 38-42m dengan temuan artefak keramik China masa Dinasti Ming abad 16 Masehi, guci gerabah yang diduga produksi Singburi, Thailand, dan meriam Portugis produksi Macao. Nilai parameter kualitas perairan situs sesuai dengan standar baku mutu perairan untuk wisata bahari dan biota laut. Temuan situs dan BMKT di Soasio dan Tongowai memperkuat bukti pentingnya Tidore di Jalur Rempah dan Sutra Laut dan dapat dimanfaatkan untuk ekowisata sejarah situs kapal tenggelam yang terintegrasi dengan lingkungan perairannya dan juga dengan destinasi wisata sejarah lainnya di Tidore Kepulauan.
\end{abstract}

Kata Kunci: Arkeologi Maritim, Situs Kapal Tenggelam, BMKT, Ekowisata Terintegrasi, Tidore.

\section{ABSTRACT}

Tidore is well-known for its ancient history proven by the presence of historical-archaeological remains both inland and underwater. Integrated shipwreck ecotourism could be developed with the concept of maritime history tourism and underwater archeology that is responsible for the preservation of the aquatic environment, pays attention to the integrity of local culture, and provides economic benefits which increase regional income. This study aims to determine the presence of the shipwreck site and its cargoes, to identify the historical sites, and to assess the aquatic environment for the development of integrated shipwreck ecotourism in Tidore. Maritime archaeological survey was carried out through SCUBA diving to observing the site and searching for the artifacts, bathymetry mapping, and assess the feasibility of sea environment. Artifactual analysis was employed to determine the artifact's type, age, place of origin, and its maritime historical context. Spatial analysis to locate the position of underwater sites and other historical sites was carried out for the development of the Heritage-Trail. Water quality assessment is adjusted to the Government Regulation No. 22 of 2021 concerning Implementation of Environmental Protection and Management Annex VIII. The research results showed the discovery of Soasio Site at a depth of 10-20m and Tongowai at a depth of 38-42m with the findings of Chinese 
ceramics from the Ming Dynasty period of the 16th century AD, earthenware jars produced in Singburi, Thailand, and Portuguese cannons manufactured in Macao. The water quality assessment result showed that Soasio and Tongowai site have met the water quality standards for marine tourism and marine life. The discovery of Soasio and Tongowai has strengthened the physical evidence of the significance of Tidore on the Maritime Spice and Silk Route. The development of eco-tourism-integrated maritime archaeology in Tidore is an opportunity to improve the local economy which combining the historical-underwater archaeological objects with environmental aspect in Tidore Islands.

\section{Keywords: Maritime Archaeology, Shipwreck Site, Shipwreck's Cargo, Integrated Eco-Tourism, Tidore.}

\section{PENDAHULUAN}

Indonesia sebagai negara maritim dengan 17.504 pulau dan garis pantai sepanjang $108.000 \mathrm{~km} 2$ (Prasetyo et al., 2019) mempunyai potensi sumber daya di kawasan pesisir salah satunya adalah warisan budaya bawah air (Underwater Cultural Heritage) yang tantangan pelestarian dan pengelolaannya sangat tinggi. Rizaldy \& Suryawan (2019) menyatakan bahwa di Indonesia terdapat 2.046 titik kapal tenggelam yang tersebar dari barat hingga timur perairan Indonesia. Peninggalan budaya bawah air berupa kapal karam beserta muatannya di Indonesia dapat ditemukan dari abad ke-4 sampai dengan masa Perang Dunia II(Adhityatama, 2016). Salah satu temuan bawah air terbaru dari hasil kajian Loka Riset Sumber Daya dan Kerentanan Pesisir tahun 2019 dan 2021 adalah situs kapal tenggelam beserta Benda Muatan Kapal Tenggelam (BMKT) di kawasan perairan Tidore Kepulauan.

Menurut sejarah, Kesultanan Tidore mempunyai wilayah yang sangat luas yang meliputi sebagian besar Maluku hingga ke Timur wilayah Papua. Selain itu, Kota Tidore juga mempunyai peranan besar dalam sejarah maritim Nusantara dan dunia sebagai sumber rempah-rempah dan menjadi pulau tujuan para pedagang dan petualang asing pencari rempah-rempah mulai dari ekspedisi Ferdinand Magellan - Juan Sebastian Elcano dari Spanyol dalam mengelilingi dunia yang pertama kali untuk menemukan jalur laut barat ke kepulauan rempah, Maluku. Dikarenakan tewasnya Magellan di Filipina. misi perjalanan kemudian dilanjutkan oleh Juan Sebastian Elcano dengan menggunakan kapal Victoria dan Trinidad (Nontji, 2018) dan tiba di perairan Tidore pada 1521. Victoria dan Trinidad berlabuh selama 1 (satu) bulan di Pantai Rum. Adanya persaingan dagang yang sengit antara Portugis dan Spanyol berujung pada penenggelaman kapal Trinidad oleh Portugis di perairan antara Tidore dan Ternate dan kemudian muatan kapal berupa cengkeh dirampas sementara papan-papan kayu kapal Trinidad diambil oleh Portugis untuk membuat bangunan di Benteng Kastela, Ternate.
Pada saat itu, Trinidad dan Victoria dalam perjalanan pulang dari Tidore menuju ke Spanyol (Bataviani, 2012). Selain mempunyai sisi sejarah maritim, saat ini Tidore Kepulauan merupakan salah satu daerah di Maluku Utara yang melestarikan berbagai acara festival kebudayaan yang diselenggarakan setahun sekali mengikuti hari jadi Kota Tidore Kepulauan (Folasimo et al., 2017).

Kondisi pariwisata di Tidore Kepulauan kini semakin berkembang. Akan tetapi, wisata penyelaman bawah air di Tidore Kepulauan belum menjadi daya tarik utama serta belum banyak berperan dalam kegiatan pariwisata dikarenakan belum adanya pengelolaan dari pemerintah daerah dan juga minimnya informasi mengenai spot-spot yang dapat dijadikan lokasi wisata selam. Minimnya pengetahuan pemerintah setempat dan masyarakat tentang keberadaan situs kapal tenggelam menjadikan pemerintah tidak mengetahui besarnya potensi pengembangan situs tersebut untuk peningkatan kesejahteraan dan perekonomian daerah melalui wisata minat khusus yaitu wisata selam kapal tenggelam. Selain itu, kurangnya perhatian dan kesadaran terhadap nilai penting BMKT di Tidore mengakibatkan sejumlah artefak dari bawah air situs Tongowai, Tidore yang telah diangkat ke permukaan oleh para penjarah ilegal pada tahun 1990-an saat ini terbengkalai dan sangat mengkhawatirkan kondisinya karena tidak adanya perawatan. Artefak-artefak tersebut terkesan seperti barang yang tidak berharga padahal BMKT di Tidore Kepulauan dapat menjadi salah satu daya tarik wisata sejarah dan arkeologi maritim yang sangat besar apabila dijaga dan dikelola dengan baik.

BMKT yang berada di dasar laut Tidore, yaitu dari situs Soasio dan Tongowai yang telah ditumbuhi terumbu karang dan menjadi rumah ikan mempunyai daya tarik sendiri dari segi ekologi ditambah artefak tersebut memiliki nilai sejarah terkait pelayaran dan perdagangan internasional pada abad 15-17 M. Kondisi tersebut dapat menjadi daya tarik ekowisata yang menjadi andalan wisata bahari yang dipadukan dengan 
potensi arkeologi maritim di Tidore Kepulauan. Ekowisata merupakan suatu konsep untuk melindungi sumber daya potensial disertai dengan mempromosikan pengembangan suatu daerah yang berkelanjutan (Ross \& Wall, 1999). Penelitian mengenai wisata bahari dan ekowisata di Tidore belum banyak dilakukan. Kajian (Gamtohe et al., 2019) menyebutkan bahwa Pulau Maitara di Kota Tidore mempunyai potensi untuk wisata bahari namun belum mempunyai fungsi sebagai lokasi wisata bahari. Sementara itu, kajian ekowisata terintegrasi situs kapal tenggelam di Tidore Kepulauan belum pernah dilakukan. Tujuan penelitian ini adalah untuk mengetahui keberadaan situs kapal tenggelam beserta identifikasi BMKT yang dikandungnya, inventarisasi tempat bersejarah di Tidore, serta menilai kesesuaian lingkungan perairan untuk pengembangan ekowisata terintegrasi situs kapal tenggelam di Tidore untuk mendukung pengembangan terintegrasi wisata laut dan sejarah-arkeologi maritim.

\section{BAHAN DAN METODE}

\section{Waktu dan Tempat Penelitian}

Lokasi penelitian berada di pesisir dan perairan Kota Tidore Kepulauan, Maluku Utara, Indonesia (Gambar 1). Kegiatan survei pengumpulan data dilakukan pada bulan Maret 2021 dengan fokus wilayah penelitian di Situs Soasio, Kelurahan Soasio, Kecamatan Tidore dan Situs Tongowai, Kelurahan Tongowai, Kecamatan Tidore Selatan, Kota Tidore Kepulauan, Provinsi Maluku Utara.

\section{Alat dan Bahan Penelitian}

Alat yang digunakan dalam riset ini adalah GPS, TOA Water Quality Checker, sedimen trap, instrumen batimetri, laptop, komputer, kamera bawah air yang digunakan untuk dokumentasi objek penelitian, dan peralatan selam. Sedangkan bahan yang digunakan ialah tagging artefak, kertas kalkir bawah air, aquades, perlengkapan pencatatan, dan perlengkapan pengangkatan artefak.

\section{Metode Penelitian}

Data yang dikumpulkan dan dianalisis adalah data primer dan data sekunder. Data primer didapatkan langsung di lapangan meliputi data arkeologi bawah air berupa situs dan temuan BMKT yang diambil melalui penyelaman, dokumentasi bawah air berupa fotografi dan videografi bawah air, data batimetri, data kualitas perairan, dan hasil observasi biota laut di lokasi situs. Observasi visual, pemasangan baseline dengan meteran dari 0 - 80m yang membentang dari Barat ke Timur

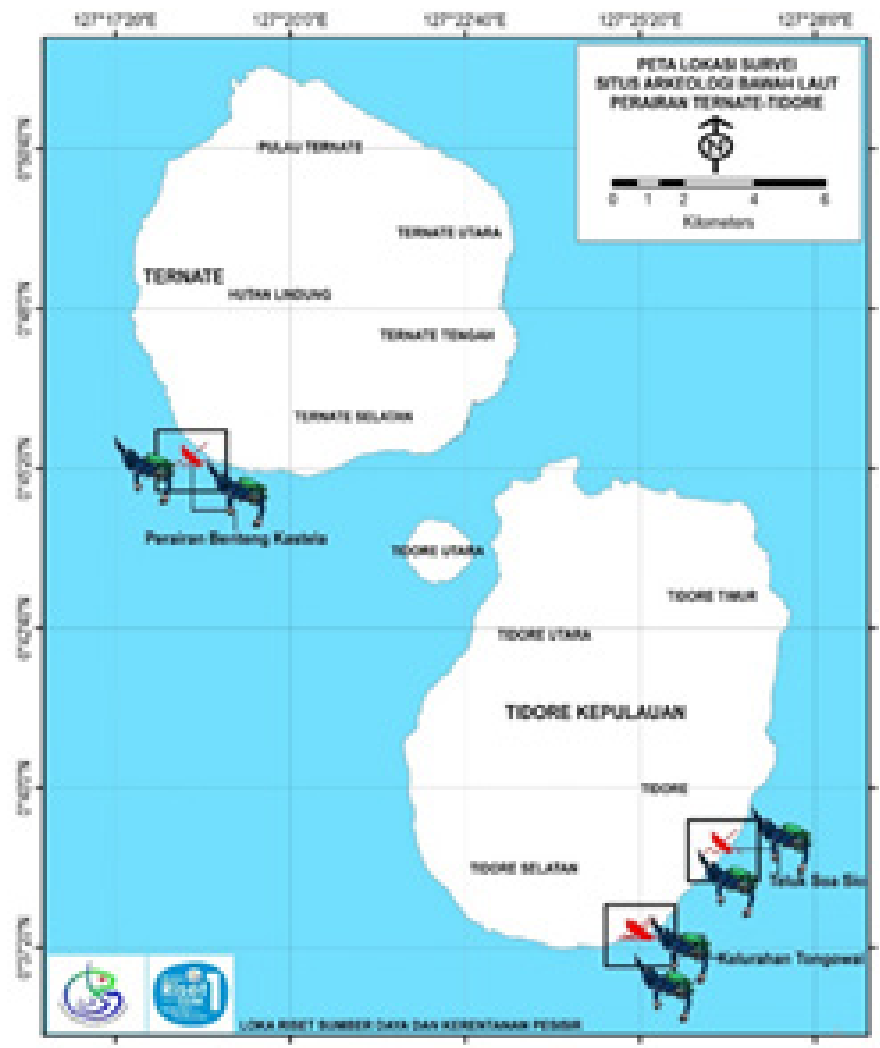

Gambar 1. Peta Lokasi Penelitian di Soasio dan Tongowai. Figure 1. Map of Research Sites in Soasio and Tongowai. 
di kedalaman $18 \mathrm{~m}$, pemberian label/tagging terhadap artefak yang ditemukan, pencatatan, serta pengangkatan sampel artefak dilakukan di Situs Soasio (Gambar 2). Pemasangan identitas artefak/label disesuaikan dengan kode lokasi dan nomor urutnya. Nomor dipasang pada objek artefak dan langsung didokumentasi agar dapat diangkat sewaktu-waktu untuk sampel. Keletakan temuan artefak di bawah air dipetakan masing-masing sehingga ketika dianalisis secara spasial akan terlihat posisi keletakan masing-masing artefak di situs tersebut dan juga di antara objek sejarah-arkeologi maritim lainnya. Artefak yang telah ditandai dengan nomor kemudian didokumentasikan melalui foto dan gambar. Foto berguna untuk mengidentifikasi artefak lebih lanjut yang tidak dapat dilakukan di dalam air karena waktu yang terbatas. Artefak-artefak juga diukur dari meteran yang terpasang sebagai baseline. Hasil gambar menunjukkan bahwa sebaran artefak di Soasio berada di area antara 20 - 60m arah Barat-Timur dan $20 \mathrm{~m}$ arah Utara. Sementara itu, observasi visual dilakukan di situs Tongowai.

Tracking tempat-tempat penting bersejarah yang ada di Kelurahan Soasio dengan menggunakan GPS. Pengambilan sampel air menggunakan TOA Water Quality checker dilakukan di Situs Soasio dan Tongowai. Data sekunder didapatkan secara langsung maupun secara tidak langsung dari buku, catatan, serta arsip yang telah dipublikasikan maupun yang belum dipublikasikan secara umum. Data sekunder meliputi data kedalaman dari batimetri nasional yang dikeluarkan oleh Badan Informasi Geospasial dan arsip sejarah mengenai Tidore Kepulauan dan Maluku Utara.

\section{Analisis Data}

Analisis data untuk identifikasi BMKT adalah analisis data artefaktual terhadap sampel BMKT yang diangkat dari Situs Soasio maupun temuan dari Situs Tongowai untuk mengetahui jenis dan tipe artefak, umur, dan tempat asal produksi. Sampel diidentifikasi secara morfologis terkait ukuran, bentuk, atribut yang melekat pada objek, serta identifikasi teknik pembuatan dan penelusuran waktu relatif pembuatannya berdasarkan atribut yang melekat pada objek tersebut. Data posisi keletakan situs dan data tracking GPS tempat-tempat penting bersejarah di sepanjang pesisir dekat situs Soasio dan Tongowai dianalisis dengan tujuan untuk mengetahui sebaran spasial dari situs-situs tersebut sehingga dari plotting posisi akan diketahui posisi keletakan situs kapal tenggelam Soasio dan Tongowai terhadap keletakan tempat-tempat penting bersejarah yang ada di Tidore untuk kepentingan pengembangan wisata terintegrasi wisata sejarah arkeologi maritim.

Artefak yang diangkat untuk sampel untuk diidentifikasi lebih lanjut berjumlah 22 sampel. Setelah diangkat, sampel artefak tersebut kemudian dibersihkan, diukur, dan didesalinasi untuk dipamerkan di Museum Sonyine Malige yang terletak di Kelurahan Soasio. Objek yang diangkat terdiri dari fragmen keramik berupa piring dan mangkuk berukuran besar dan kecil berbahan porselin dengan warna biru dan putih di bawah glasir berjumlah 11 serta piring dan mangkuk berglasir putih berjumlah 2 buah dan sisanya putih biru di bawah glasir. Fragmen guci gerabah yang berukuran besar dan kecil berjumlah 9 buah. Guci yang diangkat mempunyai bentuk dan ukuran dari 8 jenis yang berbeda. Sampel kayu yang diduga berasal dari papan kapal juga diambil untuk dilakukan uji laboratorium untuk mengetahui umur kayu. Berdasarkan hasil analisis Carbon Dating C14 yang dilakukan di Laboratorium Badan Tenaga Nuklir Nasional, diketahui bahwa sampel kayu Situs Soasio
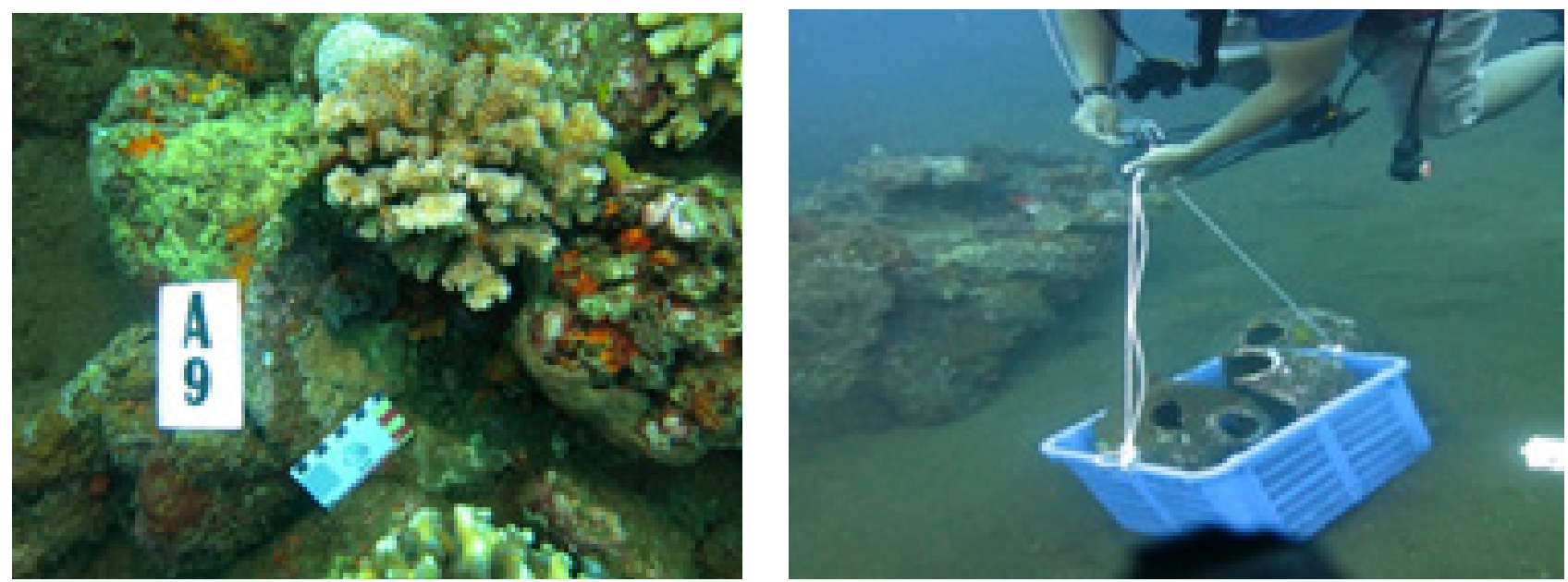

Gambar 2. Tagging Artefak dan Pengangkatan Sampel Artefak di Situs Soasio. (Sumber : Hasil Survei 2021)

Figure 2. Artifact Tagging and Removal of Artifact Samples at the Soasio Site. (Source: 2021 Survey Results) 
Analisis terhadap BMKT keramik dilakukan dengan mengidentifikasi beberapa aspek, di antaranya adalah pengklasifikasian objek berdasarkan jenis bentuknya; pengukuran dimensi objek untuk menentukan klasifikasi objek; identifikasi pola hias dan teknik; identifikasi bahan; identifikasi keberadaan ciri-ciri khusus yang dapat dijadikan sebagai dasar penentuan lokasi produksi dan rentang waktu produksinya; serta konteks sistem yang melingkupi objek tersebut sehingga objek keramik tersebut berada di Perairan Tidore. Panduan analisis keramik merujuk kepada Rangkuti et al. (2008).

Analisis bentuk dapat diawali dengan model bentuk umum wadah. Sampel keramik dari Tidore secara umum dapat disebut wadah. Wadah-wadah tersebut kemudian diklasifikasikan berdasarkan bentuknya menjadi Guci (Jambangan), Mangkuk/Pasu, dan Piring (Gambar 3). Adapun bentuk objek material pasti akan terkait dengan fungsinya, walaupun hanya manusia masa lalu pengguna wadah tersebutlah yang tahu persis fungsinya, namun dalam ilmu arkeologi pengidentifikasian fungsi dapat dilakukan dengan menyelaraskan dengan jejak bentuk bendanya, konteks asosiasinya, serta keletakan dan matriks yang melingkupi objek tersebut, dengan merujuk istilah form follow function (Purnawibowo et al., 2019). Uraian atas analisis bentuk tersebut adalah sebagai berikut :

\section{Bentuk Guci/Jambangan}

Secara umum, Guci merupakan wadah yang memiliki bentuk model mendekati jambangan, namun dalam kenyataannya bagian badannya memiliki diameter yang lebih besar dibandingkan bagian tepian dan dasarnya (Gambar 4). Teknik pengerjaannya dibuat dengan teknik roda putar. Adapun teknik hiasnya

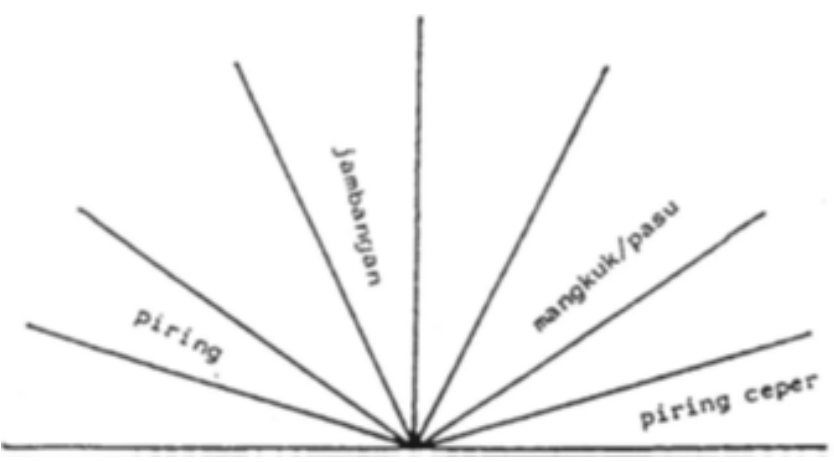

Gambar 3. Model Pengenalan Bentuk Umum Wadah. (Sumber: Orton, 1980)

Figure 3. Model of Recognition of General Shapes of Containers. (Source: Orton, 1980)

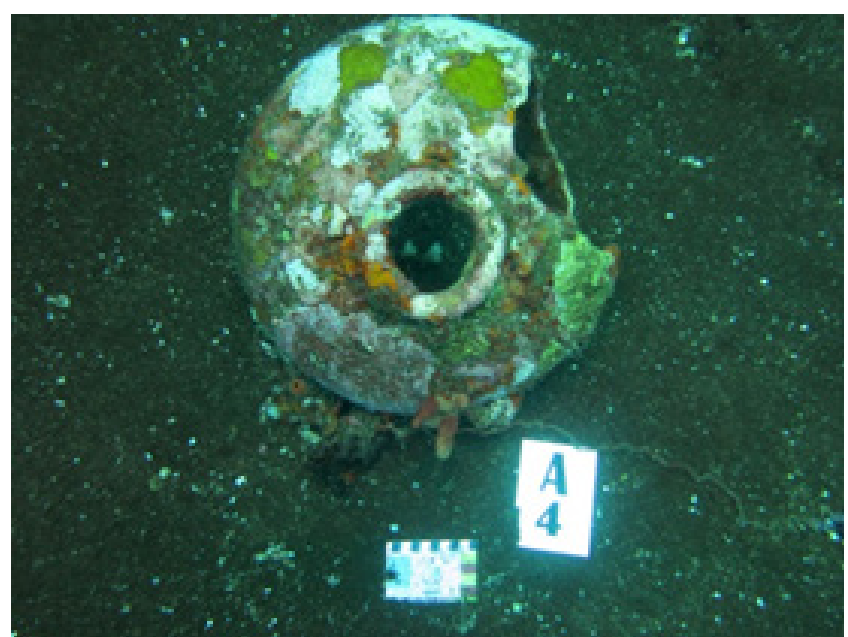

Gambar 4. Guci Gerabah dari Situs Soasio. (Sumber : Hasil Survei 2021)

Figure 4. Pottery Jars from the Soasio Site. (Source: 2021 Survey Results)

bervariasi ada yang lukis, gores, dan cap ataupun tera. Berdasarkan bahan yang dipakai untuk membuatnya terdapat dua bahan, yaitu stoneware atau gerabah dan porselin (Purnawibowo et al., 2019). Guci yang ditemukan di Tidore adalah guci berbahan stoneware.

\section{Bentuk Mangkuk}

Secara umum, Mangkuk merupakan wadah yang memiliki bentuk model mangkuk, dengan spesifikasi diameter bagian tepian akan lebih besar atau sama dengan bagian dasarnya dan kemiringan bagian badan lebih dari atau sama dengan $45^{\circ}$. Teknik pengerjaannya dibuat dengan teknik roda putar. Adapun teknik hiasnya bervariasi ada yang lukis, gores, dan cap ataupun tera. Berdasarkan bahan yang dipakai untuk membuatnya ada dua jenis bahan, yaitu stoneware dan porselin. Mangkuk yang ditemukan di Tidore adalah mangkuk porselin atau keramik.

\section{Bentuk Piring}

Secara umum, piring merupakan wadah yang memiliki bentuk model piring dengan spesifikasi diameter bagian tepian akan lebih besar dibandingkan dengan bagian dasarnya dan kemiringan bagian badan kurang dari $45^{\circ}$ (Gambar 5 dan 6). Teknik pengerjaannya dibuat dengan teknik roda putar. Adapun teknik hiasnya bervariasi yaitu lukis, gores, dan cap ataupun tera. Berdasarkan bahan yang dipakai untuk membuatnya terdapat dua jenis bahan, yaitu stoneware dan porselin. Piring yang ditemukan di Tidore adalah piring porselin atau keramik.

Analisis aspek keruangan didapat dari hasil identifikasi fragmen keramik dari perairan Tidore sebagai lokasi 


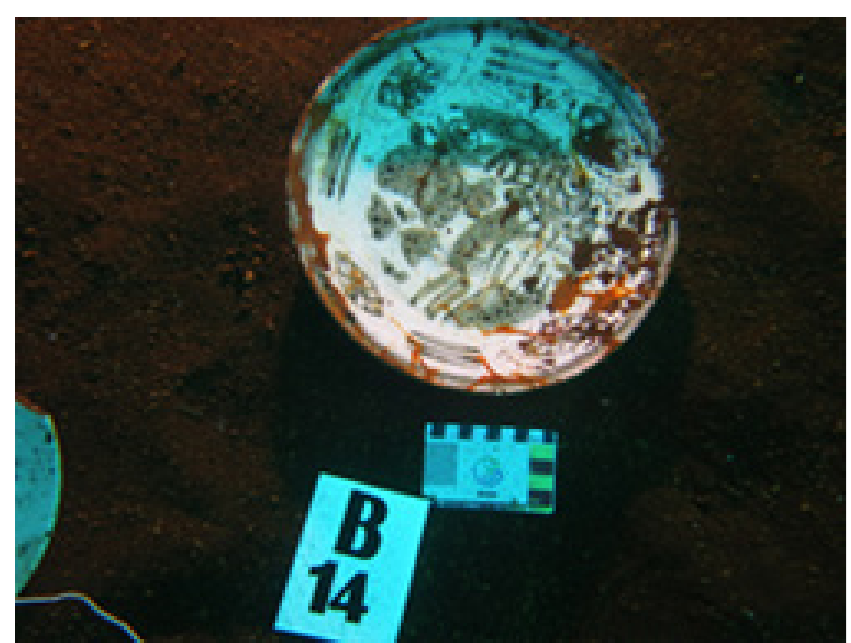

Gambar 5. Piring Keramik Swatow dari Dinasti Ming Masa Kaisar Wanli dari Situs Soasio. (Sumber : Hasil Survei 2021)

Figure 5. Swatow Ceramic Plate from Emperor Wanli's Ming Dynasty from Soasio Site. (Source: 2021 Survey Results)

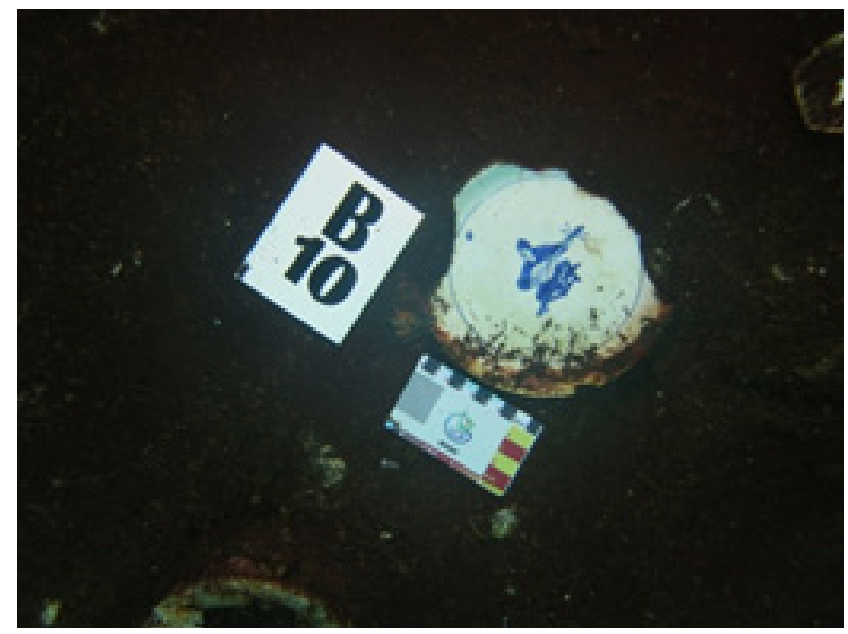

Gambar 6. Piring Keramik dari Dinasti Ming Masa Kaisar Tianqi dari Situs Soasio. (Sumber : Hasil survei 2021)

Figure 6. Ceramic Plates from the Ming Dynasty of Emperor Tianqi from Soasio Site. (Source: 2021 survey results)

benda tersebut ditemukan, serta lokasi benda tersebut diproduksi. Kedua hal tersebut ditelusuri melalui kajian atas bahan dan bentuk wadah; gaya seni/pola hiasnya; serta identifikasi inskripsi/tanda/huruf yang dapat terbaca di bagian wadah tersebut apabila ada. Produksi keramik berjenis biru putih dan terdapat yang berwarna sedikit keabuan yang ditemukan situs Soasio berbentuk mangkuk dan piring porselin dengan motif hias flora dan fauna berasal dari masa Dinasti Ming. Selain warna biru putih dan motif flora fauna, pada bagian kakinya terdapat tempelan pasir pantai, jenis keramik ini dikenal dengan sebutan keramik Swatow/
Zhangzou, China yang diproduksi pada masa abad ke-16 hingga ke-17 Masehi (Eriawati, 2012-2013; Adhiyatman, 2000), terutama dari masa kekaisaran Wanli yang memerintah pada 1572-1620 M. Selain motif flora fauna, terdapat piring keramik biru putih bermotif manusia sedang memegang alat musik. Jenis motif ini dikenal pada masa kekaisaran Tianqi dari Dinasti Ming yang memerintah pada tahun 1620-1627 M.

Sementara itu, jenis guci/jambangan gerabah berwarna coklat polos yang ditemukan di bawah air Situs Soasio dan Tongowai diproduksi dari wilayah Asia Tenggara daratan yaitu Singbhuri, Thailand. Masa produksinya berasal dari abad ke-15 Masehi hingga ke-17 Masehi. Jenis guci ini menjadi pesaing utama Cina dalam perdagangan barang keramik di Nusantara pada masa itu (Purnawibowo et al., 2019). Berdasarkan uraian hasil identifikasi tersebut, jumlah populasi gerabah yang paling banyak populasinya adalah keramik Thailand dari masa abad ke-15 hingga abad ke-17 Masehi yang disusul oleh barang China.

Hasil pengukuran parameter kualitas perairan di Situs Soasio dan Tongowai dianalisis sesuai Peraturan Pemerintah No. 22 Tahun 2021 tentang Penyelenggaraan Perlindungan dan Pengelolaan Lingkungan Hidup Lampiran VIII mengenai kesesuaian untuk wisata bahari dan kehidupan biota laut. Parameter yang diukur dapat dilihat pada Tabel 1.

Perhitungan Indeks Kesesuaian Wisata Selam dengan parameter kecerahan, kecepatan arus, kedalaman situs, dan kedalaman keberadaan terumbu karang juga dilakukan dan dapat dilihat pada Tabel 2. Kecepatan arus laut di sekitar lokasi situs diolah dan dianalisis dengan melakukan simulasi numerik untuk mengetahui kondisi arus pada waktu kondisi pasang maupun kondisi surut.

Tabel 1. Parameter kualitas perairan PP No.22 Tahun 2021

Table 1. Water quality parameters of PP No.22 of 2021

\begin{tabular}{ll}
\hline Wisata Bahari & Biota \\
\hline $\mathrm{pH}=7-8,5$ & $\mathrm{pH}=7-8,5$ \\
$\mathrm{DO}=>5$ & $\mathrm{DO}=>5$ \\
$\mathrm{Sal}:$ Alami & $\begin{array}{l}\text { Sal }: \text { Alami } \\
\text { Coral 33-34, } \\
\text { Mangrove sd 34, } \\
\end{array}$ \\
Lamun 33-34 \\
Turbidity $=5$ & Turbidity $=5$ \\
\hline
\end{tabular}


Tabel 2. Matriks Kesesuaian Wisata Selam

Table 2. Diving Suitability Matrix

\begin{tabular}{|c|c|c|c|c|c|c|c|c|c|c|}
\hline No & Parameter & Bobot & $\begin{array}{l}\text { Kategori } \\
\text { (S1) }\end{array}$ & Skor & $\begin{array}{l}\text { Kategori } \\
\text { (S2) }\end{array}$ & Skor & $\begin{array}{l}\text { Kategori } \\
\text { (S3) }\end{array}$ & Skor & $\begin{array}{l}\text { Kategori } \\
\text { (N) }\end{array}$ & Skor \\
\hline 1 & $\begin{array}{l}\text { Kecerahan } \\
\text { Perairan (m) }\end{array}$ & 5 & $>10$ & 3 & $>5-10$ & 2 & $3-5$ & 1 & $<2$ & 0 \\
\hline 2 & $\begin{array}{l}\text { Tutupan } \\
\text { Komunitas } \\
\text { Karang (\%) }\end{array}$ & 5 & $>75$ & 3 & $>50-75$ & 2 & $25-50$ & 1 & $<25$ & 0 \\
\hline 3 & Jenis Life Form & 3 & $>12$ & 3 & $>7-12$ & 2 & $4-7$ & 1 & $<4$ & 0 \\
\hline 4 & $\begin{array}{l}\text { Jenis Ikan } \\
\text { Karang }\end{array}$ & 3 & $>100$ & 3 & $50-100$ & 2 & $20-<50$ & 1 & $<20$ & 0 \\
\hline 5 & Kedalaman Situs & 3 & $>30$ & 3 & $>20-30$ & 2 & $>10-20$ & 1 & $<5-10$ & 0 \\
\hline 6 & Kecepatan Arus & 1 & $0-15$ & 3 & $>5-30$ & 2 & $>30-50$ & 1 & $>50$ & 0 \\
\hline 7 & $\begin{array}{l}\text { Kedalaman } \\
\text { Terumbu (m) }\end{array}$ & 1 & $6-15$ & 3 & $\begin{array}{l}>15-20 \\
3-<6\end{array}$ & 2 & $>20-30$ & 1 & $\begin{array}{l}>30 \\
<3\end{array}$ & 0 \\
\hline
\end{tabular}

Sumber: Yulianda, 2007

Keterangan:

Nilai Maksimum $=63$

$\mathrm{S} 1=$ Sangat sesuai, dengan nilai $75-100 \%$

S2 = Cukup Sesuai, dengan nilai $50-<75 \%$

$\mathrm{S} 3=$ Sesuai bersyarat, nilai $25-<50 \%$

$\mathrm{N}=$ Tidak sesuai, dengan nilai $<25 \%$

Rumus yang digunakan untuk kesesuaian wisata ditunjukkan oleh persamaan 1 .

$$
\mathrm{IKW}=\sum\left(\frac{N_{i}}{N_{\text {maks }}}\right) x 100 \%
$$

Keterangan:

IKW : Indeks Kesesuaian Wisata

Ni : Nilai Parameter ke-i (Bobot x Skor)

$\mathrm{N}_{\text {maks }} \quad$ : Nilai Maksimum dari suatu kategori Wisata

\section{HASIL DAN PEMBAHASAN}

\section{Kondisi Artefak dan Situs}

Berdasarkan hasil penyelaman yang dilakukan di Situs Soasio, ditemukan sebaran artefak berupa keramik mangkuk dan piring serta guci gerabah pada kedalaman 10-20 meter di bawah permukaan laut. Kondisi artefak banyak yang sudah berupa fragmen dan tidak utuh lagi. Artefak yang ditemukan sebagian berada di atas permukaan dasar laut, dan sebagian ditemukan terkubur di dasar laut dan tertutupi sedimen. Terdapat bentangan kayu sepanjang $4 \mathrm{~m}$ orientasi UtaraSelatan yang diduga sebagai bagian dari badan kapal, serta terdapat batu-batu yang diduga sebagai batu penyeimbang kapal atau ballast stone. Sampel artefak yang diangkat dari Situs Tongowai adalah 7 buah piring keramik yang terdiri dari 6 piring biru putih di bawah glasir dan satu piring glasir putih; 6 mangkok keramik yang terdiri dari 5 mangkok biru putih dan 1 mangkok porselin putih; 7 buah guci gerabah besar; dan 2 buah guci gerabah kecil. Dari 7 piring yang diangkat, satu piring keramik dalam kondisi utuh dan sisanya berupa fragmen. Fragmen mangkuk dan piring keramik biruputih berdasarkan hasil analisis artefaktual dapat diidentifikasi berasal dari China masa Dinasti Ming dari kekaisaran Wanli dan Tianqi pada abad ke-16-17. Sampel artefak setelah diangkat kemudian dibersihkan, diukur, didokumentasikan, dan dihilangkan garamnya untuk kemudian dipamerkan di museum lokal, Sonyine Malige Museum.

Sementara itu, di Situs Tongowai pada kedalaman 38$42 \mathrm{~m}$ ditemukan sebuah meriam utuh dengan kondisi beberapa bagian meriam tertutup oleh sedimen (Gambar 8). Ditemukan juga beberapa drum dan talitali pengikat yang terikat pada meriam yang diduga merupakan salah satu usaha untuk mengangkat meriam ke darat yang dilakukan oleh para penjarah illegal pada tahun 1990-an sesuai dengan informasi dari masyarakat lokal. Sebuah meriam lain dari Situs Tongowai telah diangkat oleh para penjarah dan saat ini tersimpan di halaman Guest House milik Pemerintah Kabupaten Halmahera Utara di Ito Gapura, Kota Tidore. Meriam tersebut berdasarkan motif dan inskripsi yang terpahat di badan meriam menunjukkan bahwa meriam tersebut adalah meriam Portugis yang diproduksi di Macao oleh manufaktur Manuel Tavares Boccaro dari tahun 
1627. Dari pengangkatan illegal tahun 1998 di Situs Tongowai, terdapat guci gerabah berjumlah ratusan yang saat ini tersimpan di gudang Guest House di Ito Gapura. Guci-guci gerabah dari Situs Tongwai yang masih berada di bawah air dan juga ratusan guci di Gudang Ito Gapura mempunyai kesamaan jenis bentuk dan bahan dengan guci gerabah yang ditemukan di Situs Soasio (Gambar 7).

Posisi keletakan Situs Soasio berada tepat di depan Benteng Tahula yang merupakan benteng pertahanan Spanyol hingga tahun 1662. Posisi Benteng Tahula sangat strategis dan dibangun di atas bebatuan karang yang tinggi sehingga dapat digunakan untuk mengamati wilayah daratan dan lautan Tidore. Benteng Tahula mulai dibangun pada tahun 1610 atas perintah Gubernur Spanyol bernama Cristobal de Azcqueta Menchacha dan diberi nama Santiago de los Caballeros de Tidore. Pada tahun 1615, pembangunannya selesai di masa Gubernur baru bernama Don Jeronimo de
Silva. Gubernur tersebut mengubah nama benteng menjadi Santiago Caualleros de los de la de ysla Tidore. Benteng digunakan sebagai bangunan militer hingga tahun 1662. Benteng Tahula berada dekat Kedaton Kesultanan Tidore, tepatnya di sebelah Selatannya.

Untuk mencapai situs bawah air Soasio, para penyelam dapat melakukan beach entry dengan mudah kemudian berjalan kaki sekitar 20m pada kedalaman sekitar 1m (Gambar 9). Para penyelam kemudian dapat mulai turun dari kedalaman $2 \mathrm{~m}$ dan berenang ke arah Timur. Pemandangan di bawah air cukup indah dengan banyaknya terumbu karang berbagai jenis dan bentuk serta ikan yang bermacam-macam. Kondisi air laut yang bening membuat jarak pandangnya jauh dan dapat mencapai 10-20m. Penyelaman di Soasio dapat dilakukan sebanyak 2 (dua) kali sehari dan tidak tergantung pada cuaca karena kondisi perairan yang dekat dengan daratan di Tanjung Soasio sangat tenang dengan kecepatan arus yang rendah serta visibility yang
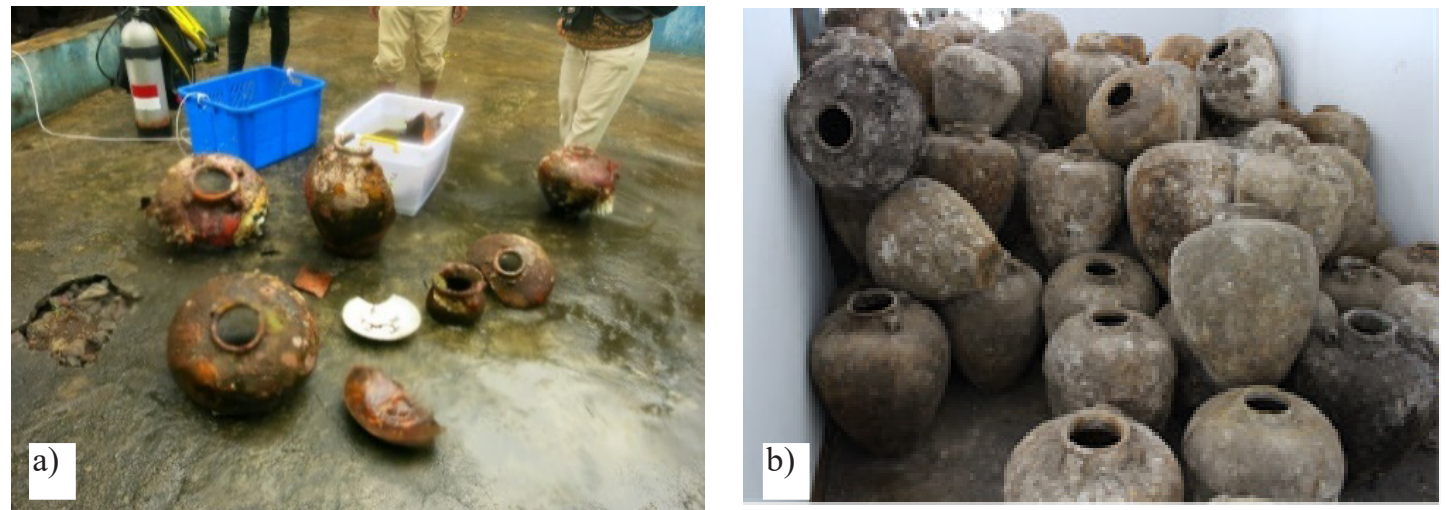

Gambar 7 a). Sampel Guci Gerabah dari Situs Soasio hasil Survei 2021, b). Guci Gerabah yang Diangkat Penjarah dari Situs Tongowai tahun 1998. (Sumber : Hasil survei 2021)

Figure 7 a). Samples of pottery urns from the Soasio Site from the 2021 Survey, b). Pottery Jars Lifted by Looters from Tongowai Site in 1998. (Source: 2021 survey results)
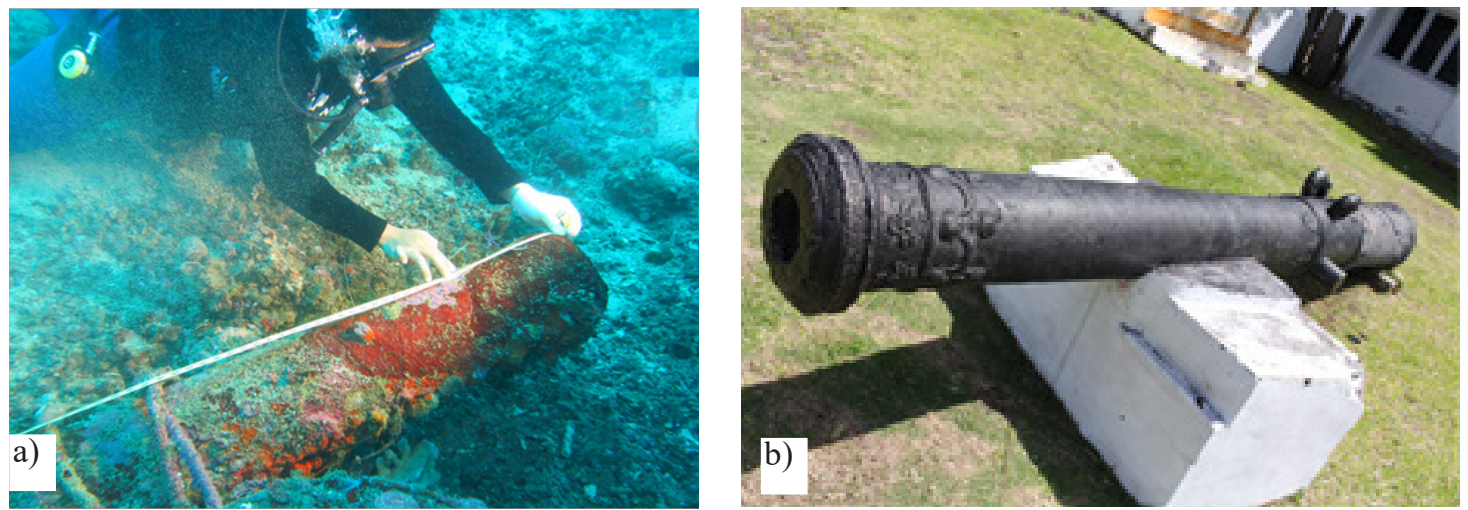

Gambar 8. a). Temuan Meriam di Situs Tongowai, b). Meriam Portugis dari Situs Tongowai yang diangkat Penjarah Tahun 1998 dan saat ini tersimpan di Ito Gapura

Figure 8. a). Cannon Finding at Tongowai Site, b). Portuguese cannon from Tongowai Site which was appointed by the Looters in 1998 and is currently stored in Ito Gapura

JURNAL KELAUTAN NASIONAL, Vol 16, No 3, Desember 2021, Hal. 169-184 


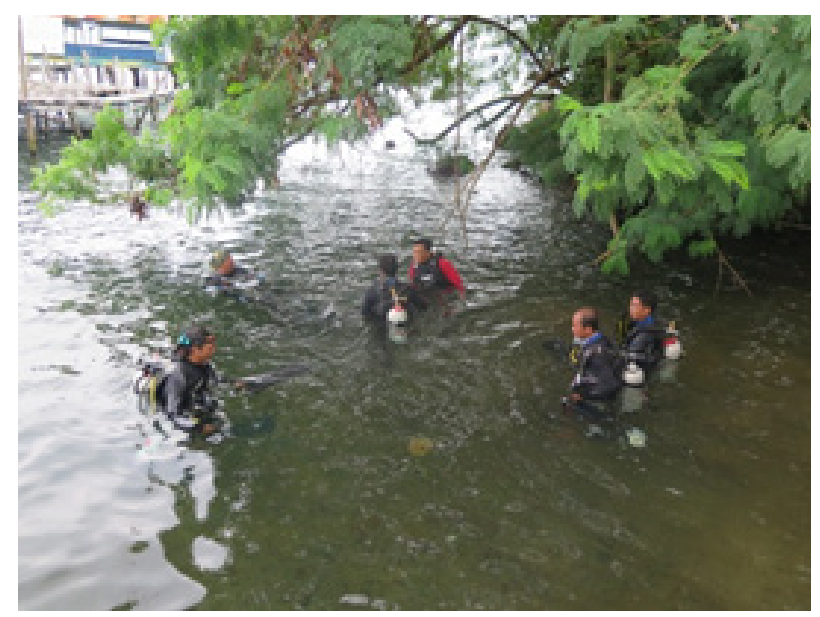

Gambar 9. Situs Soasio yang mudah dijangkau oleh Para Penyelam dengan Beach Entry.

Figure 9. Soasio Sites Easily Reachable by Divers with Beach Entry.

jernih sehingga kegiatan penyelaman dapat dilakukan pada waktu kapan saja bahkan night dive. Situs Tongowai berada di belakang perumahan penduduk di Kelurahan Tongowai. Situs Tongowai juga dapat diakses dengan mudah oleh para penyelam melalui beach entry dan juga dapat menggunakan perahu. Situs Tongowai mempunyai koloni terumbu karang yang indah dan dapat mulai ditemukan sejak kedalaman $3 \mathrm{~m}$. Di Kedalaman $10 \mathrm{~m}$ juga terumbu karang masih baik dan beraneka ragam. Kondisi arus dan perairn juga cukup tenang di Situs Tongwai sehingga memudahkan aktivitas penyelaman.

Jenis ikan karang yang ditemukan di Situs Soasio dan Tongowai berupa Ikan Indikator atau ikan Asosiasi serta Ornamental, Chaetodon/Kepe-kepe/kup-kupu. Sedangkan Ikan Target/Ekonomis yang ditemui adalah Kerapu, kakap, baronang, ekor kuning, serta ikan pelagis/kueh dan mini barracuda. Life form di Situs
Soasio adalah Acropora sp, Merulina sp, Giniastrea $s p$, Montipora sp, Porites sp, Pectinia sp, Symphyllia sp, Favia sp, Astreopora sp, Montastrea sp, Diploastrea $s p$. Sementara di Situs Tongowai adalah Acropora.sp, Montipora sp, Seriatopora sp, Oxipora,sp, Porites.sp, Stylopora.sp, Pectinia.sp, Psammocora.sp, Galaxea, sp, Fungia.sp, Pocillopora.sp.Favia.sp, dan Hidnopora.sp, Goniastrea.sp serta Sponge, Karang lunak dan Kipas laut/Gorgonian (Gambar 10).

Kadar salinitas berkisar antara 29,1-32,6 \% dengan nilai rata-rata $31,9 \%$. Nilai DO pada hasil pengamatan berkisar antara 5,1-5,7 ppm dengan rata-rata 5,28 ppm. Rata-rata nilai $\mathrm{pH}$ sebesar 7,9 dengan kisaran nilai antara 7,14-8,14 masih di atas standar baku mutu air laut yang telah ditetapkan yaitu 7-8,5. Besarnya nilai $\mathrm{pH}$ sangat menentukan dominasi fitoplankton yang mempengaruhi tingkat produktivitas primer suatu perairan dimana keberadaan fitoplankton didukung oleh ketersediaan nutrien di laut (Megawati et al., 2014). Sementara itu, Wulandari et al. (2014) meneliti tentang TSS berkaitan dengan kekeruhan perairan menyatakan bahwa asupan TSS berasal dari muara sungai pada saat pasang, elevasi air laut lebih tinggi sehingga muara akan didominasi oleh air laut, sedangkan pada saat surut, maka elevasi air laut lebih rendah daripada air sungai maka dominasi air sungai terjadi di wilayah muara yang membawa zat-zat padat tersuspensi dan mempengaruhi ekosistem muara yang ada (Wisha et al., 2017). Sementara itu, nilai kekeruhan (turbiditas) sebesar 0 NTU dan tidak terdeteksi adanya kekeruhan sama sekali. Menurut Armita (2011), kekeruhan dapat mengganggu proses respirasi dan menurunkan kadar oksigen dalam air sehingga dapat mengganggu keberlangsungan suatu habitat. Berdasarkan hasil pengamatan kualitas perairan di Situs Soasio dan Tongowai, dapat diketahui bahwa kondisi perairan di sekitar situs masih dalam keadaan baik dan sesuai
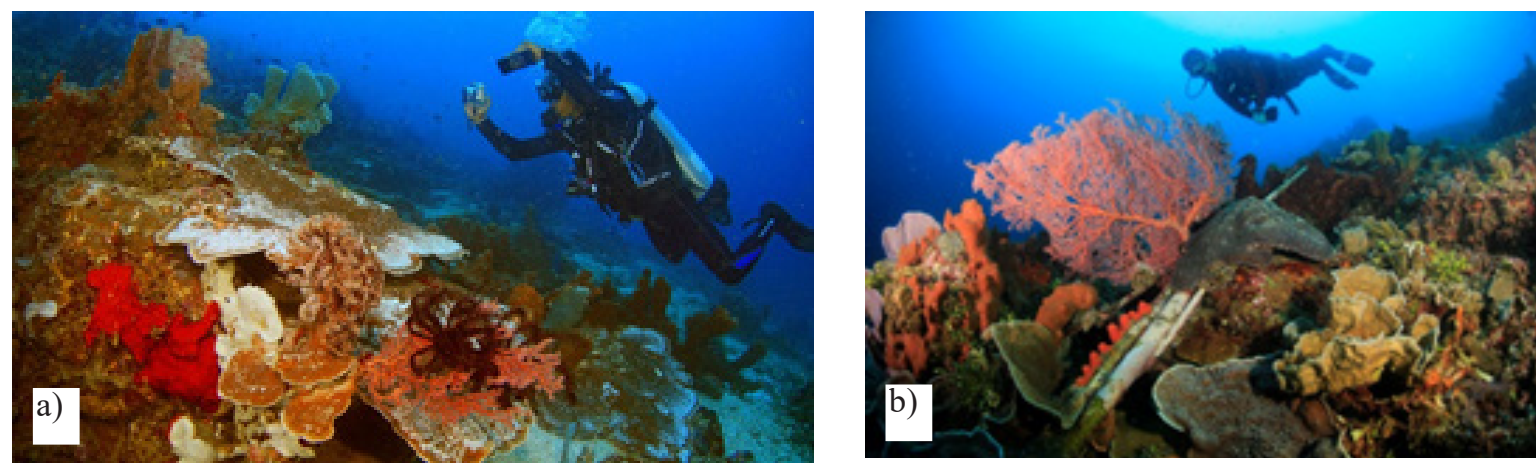

Gambar 10. a). Kondisi Terumbu Karang di Situs Soasio, b). Kondisi Terumbu Karang di Situs Tongowai. (Sumber : Hasil survei 2021)

Figure 10. a). Condition of Coral Reef at Soasio Site, b). Condition of Coral Reefs at Tongowai Site. (Source: 2021 survey results)

$\overline{\text { Ekowisata Terintegrasi Situs Kapal Tenggelam di Tidore Kepulauan, Maluku Utara - Guntur Adhi Rahmawan, Nia Nae- }}$ lul Hasanah Ridwan, Ulung Jantama Wisha, Ilham, Wisnu Arya Gemilang, Fitria Wahyu Andriani, Agus Sudaryadi, \& Irwansyah 
dengan standar baku mutu air Laut dalan PP No. 22 Tahun 2021 Lampiran VIII. Kualitas perairan dapat dilihat pada Tabel 3.

\section{Kedalaman Situs Bawah Air}

Pemetaan batimetri dilakukan untuk mengetahui kedalaman dan topografi perairan. Kedalaman perairan laut Tidore berkisar antara $0 \mathrm{sd} 150 \mathrm{~m}$ dari areal penelitian. Kedalaman $150 \mathrm{~m}$ dapat ditemui pada jarak 500 meter dari pesisir pantai dengan slope rata-rata sebesar $11,6^{\circ}$. Topografi dasar laut perairan Tidore termasuk landai dengan sedikit miring dengan kedalaman yang semakin bertambah begitu menuju ke arah laut dengan kontur yang tidak begitu rapat untuk tiap intervalnya. Slope maksimal adalah sebesar $19^{\circ}$. Kedalaman Situs Soasio dapat ditemukan pada kedalaman 10 - 20 meter sedangkan meriam di Situs Tongowai dapat ditemukan pada kedalaman 38-42 meter.

\section{Indeks Kesesuaian Wisata}

Berdasarkan dari hasil perhitungan Indeks Kesesuaian Wisata yang dapat dilihat pada Tabel 3 dan 4, kedua situs termasuk dalam kategori S2 (Cukup Sesuai) dengan nilai 77,8\% untuk Situs Siasio dan 73,02\% untuk Situs Tongowai. Perbedaan nilai tersebut terletak pada parameter kedalaman tempat ditemukannya situs dan sebaran artefak dimana Situs Soasio dapat ditemukan mulai kedalaman $10 \mathrm{~m}$ sehingga mudah diakses, sementara Situs Tongowai terletak pada kedalaman $>30$ meter yang menyulitkan akses bagi penyelam pemula apabila dikembangkan untuk wisata diving situs kapal tenggelam. Kecerahan di Situs Soasio maupun Situs Tongowai sangat baik karena mencapai lebih dari 10 meter. Akbar et al., 2018 dalam penelitiannya menyatakan bahwa kecerahan di perairan sekitar Pulau Maitara, Tidore berkisar antara $20-23$ meter. Kecepatan arus di sekitar situs Soasio dan Tongowai pada saat pasang perbani sebesar 0,04-0,09 $\mathrm{m} / \mathrm{s}$, sementara pada saat surut perbani kecepatan arus mencapai $0,02 \mathrm{~m} / \mathrm{s}$. Kecepatan arus pada saat pasang purnama mencapai $0,3 \mathrm{~m} / \mathrm{s}$ sedangkan pada saat surut purnama kecepatan arus berkisar 0-0,13 m/s.

\section{Potensi Pengembangan Wisata Sejarah Arkeologi Maritim Bawah air}

Tempat tenggelamnya kapal dan adanya peninggalan bawah air di Tidore Kepulauan berpotensi menjadi alternatif tujuan wisata yaitu untuk wisata bahari terutama untuk wisata selam bawah air di perairan tersebut. Penyelaman juga tidak hanya untuk wisata, namun juga dapat dimanfaatkan oleh para peneliti dan dive center untuk kegiatan riset, edukasi, dan sertifikasi selam. Sosmiarti \& Fahlefi (2019) pernah melakukan penelitian dengan mengembangkan kearifan budaya masyarakat lokal Soasio ke dalam paket wisata yang disebut Travel Tour Heritage. Di Indonesia, saat ini situs peninggalan bawah air belum menjadi suatu daya tarik utama dalam wisata apabila dibandingkan dengan daya tarik alam Indonesia yang memang dikenal keindahan dan keanekaragaman hayatinya (Ariadi et al., 2018). Keletakan situs Soasio dan Tongowai sangat strategis karena lokasinya berdekatan dengan situssitus sejarah-arkeologi di Tidore Kepulauan seperti terlihat pada Gambar 13. Sehingga ke depan paket wisata sejarah-arkeologi dapat ditambah dengan wisata bahari berupa penyelaman dan snorkeling di lokasi situs kapal tenggelam di Soasio dan Tongowai. Berikut

Tabel 3. Tabel Kualitas Air Situs Soasio dan Tongowai

Table 3. Table of Water Quality for Soasio and Tongowai Sites

\begin{tabular}{|c|c|c|c|c|c|c|}
\hline Kode & pH & $\begin{array}{l}\text { DO } \\
\mathrm{mg} / \mathrm{L}\end{array}$ & Salinitas \%o & $\begin{array}{l}\text { Turbidity } \\
\text { (NTU) }\end{array}$ & $\begin{array}{l}\text { Baku Mutu Kep } \\
\text { Wisata Bahari }\end{array}$ & $\begin{array}{l}\text { MenLH } \\
\text { Biota }\end{array}$ \\
\hline SS1 & 7,14 & 5,3 & 29,1 & 0 & \multirow[t]{2}{*}{$\mathrm{pH}=7-8,5$} & \multirow[t]{2}{*}{$\mathrm{pH}=7-8,5$} \\
\hline $\mathrm{SS} 2$ & 7,44 & 5,49 & 31,2 & 0 & & \\
\hline SS3 & 8,01 & 5,48 & 32 & 0 & \multirow[t]{2}{*}{$\mathrm{DO}=>5$} & \multirow[t]{2}{*}{$\mathrm{DO}=>5$} \\
\hline TW 1 & 8,14 & 5,2 & 32,1 & 0 & & \\
\hline TW2 & 8,01 & 5,7 & 31,7 & 0 & \multirow[t]{2}{*}{ Sal : Alami } & Sal : Alami \\
\hline TW3 & 8 & 5,2 & 32,3 & 0 & & Coral 33- \\
\hline TW4 & 8 & 5,1 & 32,4 & 0 & \multirow[t]{6}{*}{ Turbidity $=5$} & 34, Mangrovve \\
\hline TW5 & 8 & 5,2 & 32,4 & 0 & & sd 34, Lamun \\
\hline TW6 & 8.04 & 5,2 & 32,4 & 0 & & $33-34$ \\
\hline SS5 & 8 & 5,3 & 32,5 & 0 & & \\
\hline SS6 & 8 & 5,1 & 32,6 & 0 & & Turbidity $=5$ \\
\hline SS7 & 8 & 5,2 & 32,3 & 0 & & \\
\hline
\end{tabular}

Sumber : Pengukuran lapangan Maret 2021 


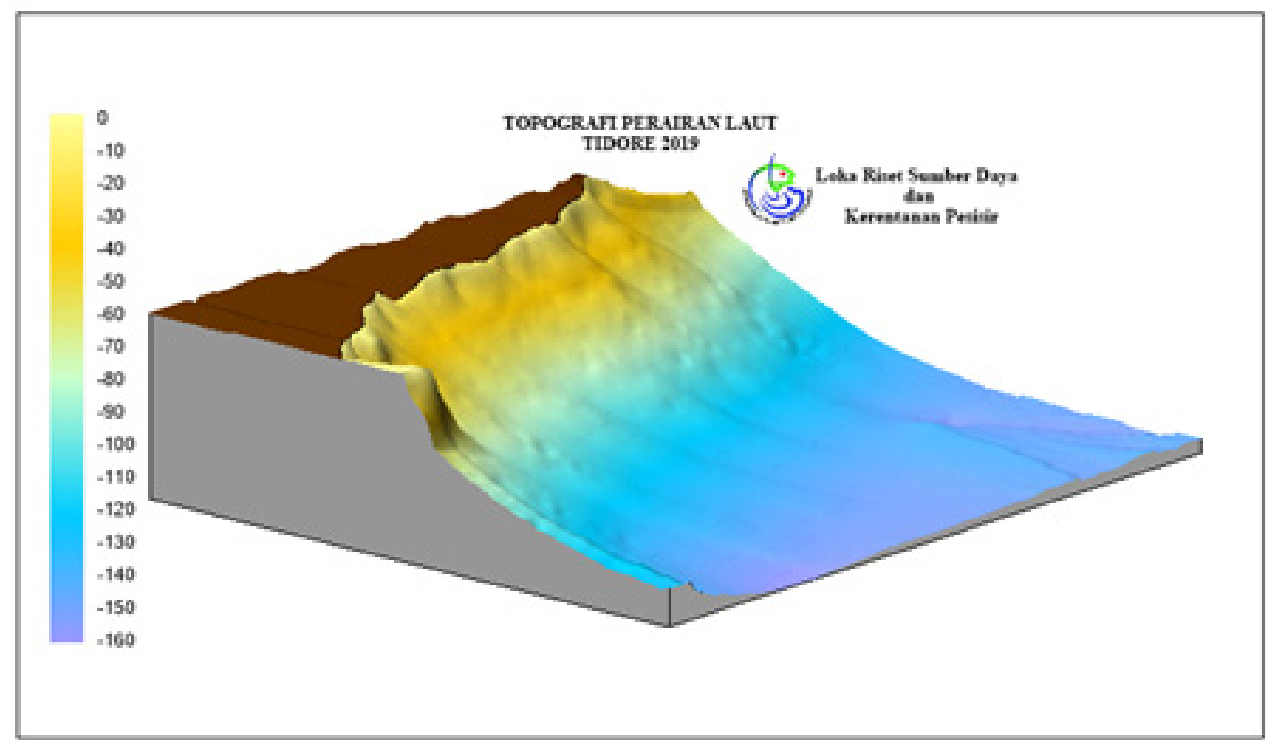

Gambar 11. Peta 3D Topografi Perairan Tidore Kepulauan.

Figure 11. Topographic 3D Map of Tidore Kepulauan Waters.

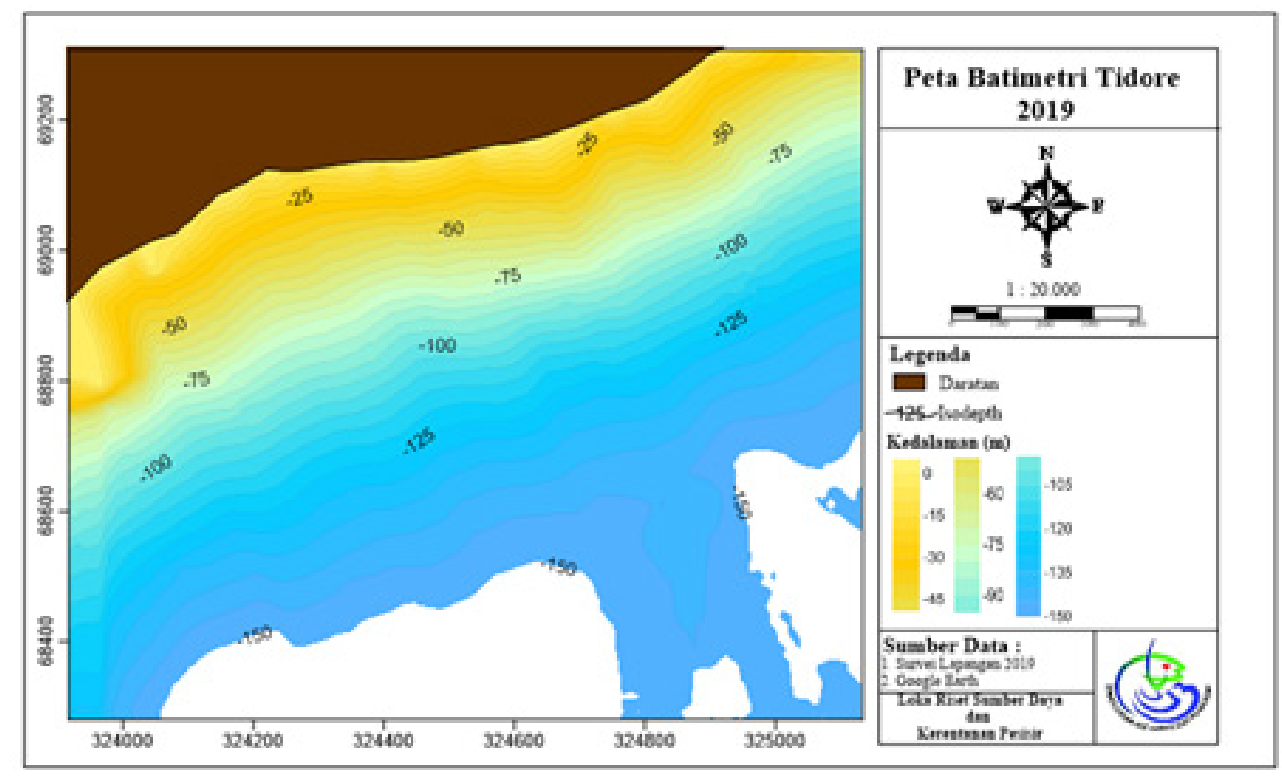

Gambar 12. Peta Kontur Kota Tidore Kepulauan.

Figure 12. Contour Map of Tidore Kepulauan City.

ini beberapa titik wisata sejarah-arkeologi di sekitar Situs Soasio dan Situs Tongowai:

- Kedaton Kesultanan Tidore; merupakan tempat tinggal para sultan dan keluarganya.

- Kedaton pertama kali berada di daerah Rum lalu kemudian pindah ke Mareku lalu kemudian pindah lagi ke Kedaton Bijinegara di Toloa, lalu ke daerah Gurabati hingga terakhir berada di Soasio sebagaimana yang sekarang.

- Mesjid Kesultanan; dibangun pada tahun 1700 M dan mengalami beberapa kali renovasi. Selain digunakan sebagai tempat ibadah sultan dan para-para tokoh kesultanan, juga digunakan sebagai tempat syiar agama Islam.

- Museum Sonyine Malige; merupakan museum yang memiliki koleksi peninggalan Kesultanan Tidore yang di antaranya terdapat A1-Qur'an tulisan tangan oleh Qalem Mansur pada tahun 1657.

- Benteng Tore; dibangun oleh Portugis di Kelurahan Soasio dan berjarak \pm 50 meter dari Keraton Kesultanan Tidore dengan ketinggian $\pm 50 \mathrm{~m}$ di atas permukaan laut.

- Benteng Tahula; dibangun oleh Spanyol yang terletak di Kelurahan Soasio dan berjarak \pm 100 meter dari 
Tabel 4. Nilai Kesesuaian Wisata Situs Soasio

Table 4. Value of Tourism Suitability of Soasio Sites

\begin{tabular}{lllll}
\hline No & Parameter & Bobot & Skor & Nilai \\
\hline 1 & Kecerahan Perairan (m) & 5 & 3 & 15 \\
2 & Tutupan Komunitas Karang (\%) & 5 & 2 & 10 \\
3 & Jenis Life Form & 3 & 2 & 6 \\
4 & Jenis Ikan Karang & 3 & 1 & 3 \\
5 & Kedalaman Situs Arkeologi & 3 & 3 & 9 \\
6 & Kecepatan Arus & 1 & 3 & 3 \\
7 & Kedalaman Terumbu (m) & 1 & 3 & 3 \\
& Ni & & & 49 \\
\hline
\end{tabular}

Tabel 5. Nilai Kesesuaian Wisata Situs Tongowai

Table 5. Value of Tourism Suitability of Tongowai Site

\begin{tabular}{lllll}
\hline No & Parameter & Bobot & Skor & Nilai \\
\hline 1 & Kecerahan Perairan (m) & 5 & 3 & 15 \\
2 & Tutupan Komunitas Karang (\%) & 5 & 2 & 10 \\
3 & Jenis Life Form & 3 & 3 & 9 \\
4 & Jenis Ikan Karang & 3 & 1 & 3 \\
5 & Kedalaman Situs Arkeologi & 3 & 2 & 6 \\
6 & Kecepatan Arus & 1 & 3 & 3 \\
7 & Kedalaman Terumbu (m) & 1 & 0 & 0 \\
& Ni & & & 46 \\
\hline
\end{tabular}

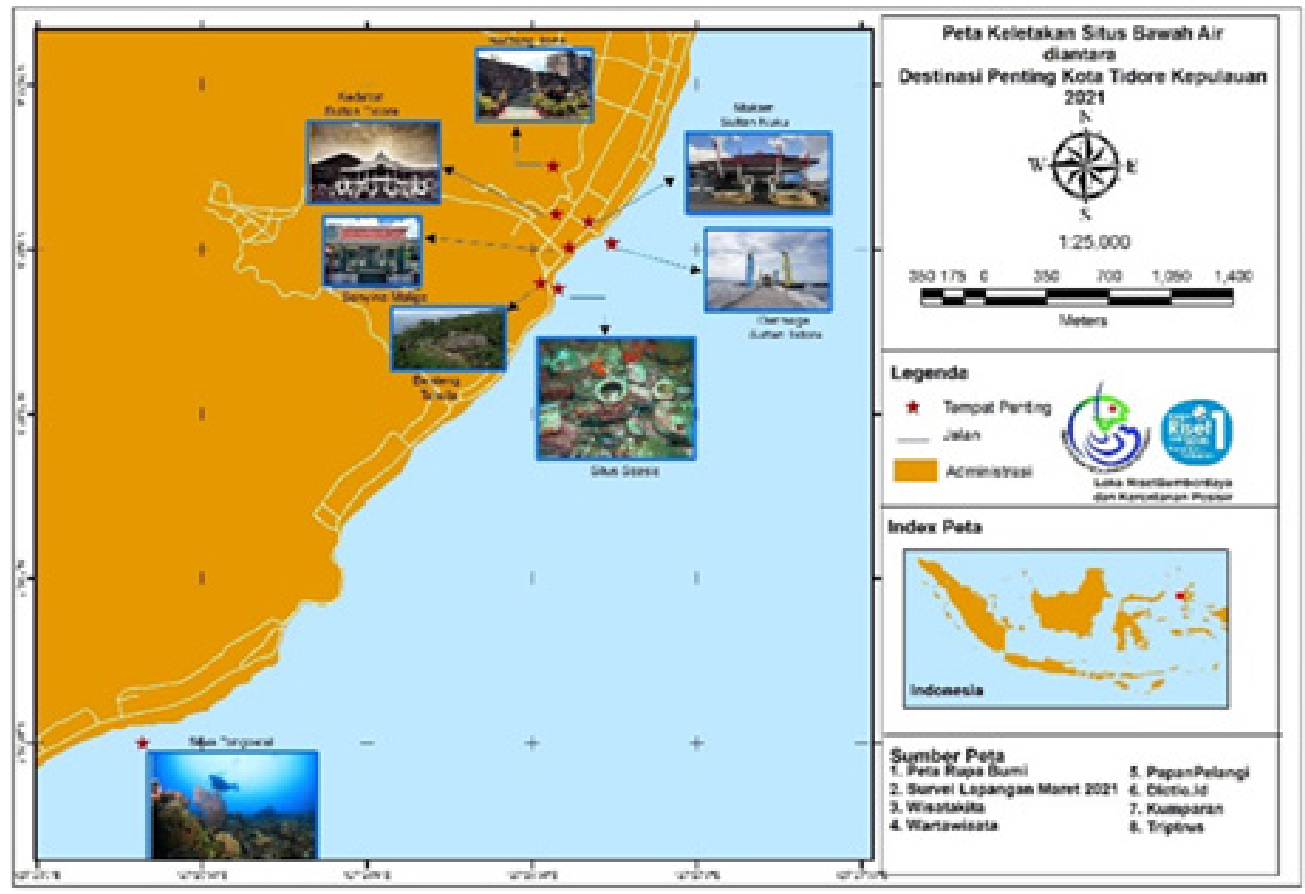

Gambar 13. Peta keletakan Situs terhadap destinasi wisata sejarah Tidore Kepulauan. Figure 13. Map of the site's position on the historical tourist destinations of Tidore Islands. 
Keraton Kesultanan Tidore dengan ketinggian $\pm 50 \mathrm{~m}$ di atas permukaan laut.

- Tugu Peringatan Kedatangan Bangsa Spanyol; merupakan tugu pendaratan Kapal Trinidad dan Victoria dari Spanyol di Tidore pada tahun 1521 Tugu ini dibangun oleh Kedutaan Besar Spanyol pada tanggal 30 Maret tahun 1993.

- Dermaga Kesultanan; dibangun pada abad ke-16 oleh Sultan Saifuddin (Jou Kota) setelah perpindahan ibukota Kesultanan dari Toloa ke Limau Timore, Soasio. Dermaga ini merupakan tempat untuk menerima tamu kesultanan dan digunakan Sultan jika akan bepergian dengan menggunakan perahu Kora-Kora

- Makam Kesultanan (Makam Sultan Nuku); adalah makam Pahlawan Nasonal Sultan Nuku yang aslinya bernama Sultan Saidul Djehad Muhammad El-Mabus Amiruddin Sjah Kaitcil Paparangan Jou Barakati.

Titik-titik penting yang bersejarah tersebut sangat berpotensi dikembangkan dalam suatu sistem paket sejarah arkeologi maritim karena letaknya yang tidak terlalu jauh serta terintegrasi dengan potensi wisata arkeologi bawah air Situs Soasio dan Situs Tongowai. Kondisi kualitas air yang baik memungkinkan tumbuhnya terumbu secara merata dan terjaga pada kedua situs tersebut. Dengan demikian, keberadaan BMKT yang ada akan menambah daya tarik dan ciri khas tersendiri bagi penikmat wisata selam. Selain itu, untuk memberikan informasi bagi masyarakat maupun pengunjung dan sebagai penambah minat untuk daya tarik wisata perlu dibuatkan suatu papan informasi maupun penyebaran informasi yang dapat dijadikan panduan bagi wisatawan untuk mengunjungi situssitus baik yang berada di pesisir maupun bawah air Tidore. Kegiatan promosi juga dapat dilakukan dengan melibatkan beberapa hotel dan bandara serta pelabuhan yang tersebar di kota Tidore untuk memajang hasil foto-foto unggulan wisata sejarah maupun bawah air supaya menambah minat para wisatawan baik lokal maupun mancanegara. Peran serta pemerintah juga diperlukan mengingat setiap tahun banyak diadakannya festival di kota tersebut sehingga memungkinkan untuk dibuat suatu event seperti perlombaan berkaitan dengan penyelaman situs sejarah di Tidore Kepulauan. Penetapan regulasi dengan peninjauan ulang Rencana Tata Ruang Wilayah Kota Tidore yang terintegrasi dengan Rencana Pengelolaan Zonasi Wilayah Pesisir dan Pulau-pulau Kecil di Kota Tidore Kepulauan dapat dilakukan untuk mengembangkan kawasan tersebut sebagai kawasan ekowisata yang terintegrasi dengan wisata sejarah arkeologi maritim.

\section{KESIMPULAN DAN SARAN}

Penemuan arkeologi bawah laut di wilayah pesisir dan air laut telah melengkapi arsip sejarah beberapa negara yang menyebutkan dan mendokumentasikan Jalur Rempah dan Sutra Maritim. Penemuan artefak dari lokasi bangkai kapal memberikan kategori baru bukti aktivitas perdagangan di sepanjang Jalur Sutra Maritim. Pola pelayaran, komoditas yang diperdagangkan, dapat tercermin dalam data kapal karam, dan menjadi gambaran bergerak dari perkembangan dan munculnya perdagangan maritim. Penelitian di Tidore Kepulauan telah dilakukan untuk mengetahui keberadaan situs kapal tenggelam beserta identifikasi BMKT yang dikandungnya, inventarisasi tempat bersejarah di Tidore, serta menilai kesesuaian lingkungan perairan untuk pengembangan ekowisata terintegrasi situs kapal tenggelam di Tidore untuk mendukung pengembangan terintegrasi wisata laut dan sejarah-arkeologi maritim.

Kerajaan Tidore di bagian timur Indonesia menjadi incaran para pedagang dan bangsa dari berbagai negara di Asia dan Eropa karena Maluku kaya akan rempah-rempah dan merupakan penghasil rempahrempah terbesar di dalam perdagangan global di masa lalu. Kedatangan peradaban asing telah meninggalkan jejaknya pada arsitektur benteng, tradisi budaya, bahasa lokal, dan keberadaan situs kapal karam beserta artefak bawah laut dari Situs Soasio dan Tongowai termasuk adanya temuan meriam Portugis yang dibuat di Macao pada tahun 1627, keramik China dari Dinasti Ming dari dua era kekaisaran yang berbeda, yaitu Kaisar Wanli dan Kaisar Tianqi serta guci penyimpanan gerabah dari Situs Soasio dan Tongowai yang kemungkinan diproduksi di Singbury, Thailand. Data artefak dari Situs Soasio dan Tongowai secara umum dapat diidentifikasi asal produksinya yaitu barang produksi Cina dari Zhangzou (Swatouw) masa abad ke-16 hingga ke-17 Masehi, dan barang produksi Thailand yang berasal dari rentang masa abad ke-15 hingga ke-17 Masehi. Penelitian warisan bawah laut dan maritim yang dilakukan mengungkapkan adanya bukti arkeologis dan sejarah maritim Tidore di Maluku Utara yang merupakan salah satu titik paling penting di Jalur Rempah dan Jalur Sutra Maritim.

Berdasarkan hasil penelitian di atas, dapat diketahui bahwa Situs Soasio dan Situs Tongwai berpotensi dijadikan sebagai destinasi ekowisata terintegrasi sejarah arkeologi maritim mengingat terdapatnya temuan situs bawah air yang mempunyai kandungan artefak bernilai sejarah dan berdasarkan nilai Indeks Kesesuaian Wisata. Selain itu, posisi situs bawah air 
yang dekat dengan tempat-tempat penting bersejarah mengindikasikan bahwa pada masa itu Kelurahan Soasio dan Tongowai merupakan daerah penting untuk para pendatang yang akan memasuki wilayah Tidore Kepulauan. Hal ini juga dibuktikan dari posisi benteng-benteng Spanyol dan Portugis yang berada pada posisi pertahanan dan pemantauan untuk melihat kapal-kapal yang akan masuk ke Kepulauan Tidore. Integrasi wisata sejarah yang ada di darat maupun wisata penyelaman arkeologi bawah air serta ekosistem lingkungannya dan juga didukung oleh kualitas air laut dan keberadaan biota laut seperti terumbu karang dan ikan di sekitar situs yang sesuai untuk wisata bahari dan pengembangan kehidupan biota laut merupakan kesempatan baik bagi Tidore Kepulauan untuk mengembangkan program ekowisata terintegrasi wisata sejarah-arkeologi yang dapat membantu meningkatkan perekonomian masyarakat dan pendapatan daerah Tidore Kepulauan.

\section{UCAPAN TERIMA KASIH}

Penulis menyampaikan terimakasih kepada Loka Riset Sumber Daya dan Kerentanan Pesisir (LRSDKP), BRSDMKP, Balai Pelestarian Cagar Budaya Jambi, Balai Pelestarian Cagar Budaya Jambi yang telah melakukan kegiatan survei secara bersama-sama di Tidore. Tak Lupa penulis juga mengucapkan terimakasih kepada DKP Tidore, para penyelam lokal dan profesional yang telah membantu dalam proses pengambilan data di lapangan. Kontributor utama dalam penulisan artikel ini adalah Guntur Adhi Rahmawan dan Nia Naelul Hasanah Ridwan.

\section{DAFTAR PUSTAKA}

Adhityatama, S. (2012). Pemodelan Jalur Aktivitas Penyelaman di Situs USAT Liberty, Tulamben, Bali. Skripsi. Departemen Arkeologi Fakultas Ilmu Budaya:Universitas Gadjah Mada.

Adhiyatman., \& Sumarah. (2000). Keramik Cina Zhangzau (Swatow) Abad 16-17 Yang Ditemukan Di Indonesia. Dalam Proceeding International Symposium for Japanese Ceramics of Archaeological Site In South-East Asia: The Maritime Relationship 0n 17th Century. Jakarta: Pusat Arkeologi dan Japan Foundation. Halaman 53-68.

Akbar, N., Ismail, F., \& Paembonan, R. E. (2018). Struktur Komunitas Ikan Karang di Perairan
Pulau Maitara, Kota Tidore Kepulauan. Provinsi Maluku Utara. Jurnal Ilmu Kelautan Kepulauan, 1(1), 1-14.

Ardiwidjaja, R. (2017). Pelestarian Tinggalan Budaya Bawah Air: Pemanfaatan Kapal Karam sebagai Daya Tarik Wisata Selam. Amerta, 35(2), 133148.

Ariadi, A. P., Prayitno, B., \& Wihardyanto, D. (2018). Analisis Produk Wisata Situs-Situs Bawah Air Sebagai Salah Satu Wisata Minat Khusus di Taman Nasional Karimunjawa. Langkau Betang: Jurnal Arsitektur, 5(1), 45. DOI:10.26418/ lantang.v5i1.25445

Armita, D. (2011). Analisis Perbandingan Kualitas Air di Daerah Budidaya Rumput Laut dengan Daerah Tidak Ada Budidaya Rumput Laut, Dusun Malelaya, Kabupaten Takalar. Skripsi. Program Studi Manajemen Sumber Daya Perairan. Jurusan Perikanan. Universitas Hasanuddin Makasar.

Bataviani, R. (2012). "Kegiatan Kemaritiman dan Perdagangan Ternate dan Tidore 15121652". Diakses pada 29 Juni 2018. Dari http:// www.academia.edu/27298290/Kegiatan Kemaritiman_dan_Perdagangan_Ternate_dan Tidore_1512_-_1652.

Folasimo, D. H., Warouw, F., \& Takumansang, E. D. (2017). Amfiteater dan Konser Hal di Pulau Tidore. Disertasi. Universitas Sam Ratulangi.

Gamtohe, F., Poli, H., \& Rengkung, M. M. (2019). Analisis Kebutuhan Prasarana dan Sarana dalam Pengembangan Kawasan Wisata Bahari di Pulau Maitara Kota Tidore Kepulauan. Spasial, 6(3), 581-590.

Megawati, C., Yusuf, M., \& Maslukah, L. (2014). Sebaran Kualitas Perairan Ditinjau dari Zat Hara, Oksigen Terlarut dan $\mathrm{pH}$ di Perairan Selat Bali Bagian Selatan. Journal of Oceanography, 3(2), 142-150.

Nontji, A. (2018). "Pengelilingan Dunia yang Pertama: Magellan Atau Panglima Awang?". Diakses pada 29 Juni 2018. http://oseanografi.lipi.go.id/ datakolom/45\%20Magellan.pdf

Orton, C. R. (1980). Mathematics in Archaeology. 
Cambridge: The University Press.

Prasetyo, K. A., Prakoso, L. Y., \& Sianturi, D. (2021). Strategi Pertahanan Laut Pemerintah Indonesia dalam Menjaga Keamanan Maritim. Strategi Pertahanan Laut, 5(1), 31-50.

Purnawibowo, S., \& Hendrawan, M. F. (2019). “Guci dan Tempayan Koleksi Museum Linggam Cahya Dalam Konteks Produksi Gambir dan Perdagangan Maritim”. Dalam Buku Budaya Maritim Nusantara Dalam Perspektif Arkeologi. Editor Lucas P. Koestoro. Jakarta: Yayasan Obor Indonesia dan Balai Arkeologi Sumatera Utara. Halaman 108 - 120.

Purnawibowo, S., \& Restiyadi, A. (2019). Laporan Penelitian Identifikasi Koleksi Keramologika Museum Linggam Cahya, Kabupaten Lingga, Provinsi Kepulauan Riau. Medan: Balai Arkeologi Sumatera Utara. Tidak dipublikasikan.

Rangkuti, N., Pojoh, I., Harkantiningsih, R. (2008). Buku Panduan Analisis Keramik. Jakarta: Pusat Penelitian Dan Pengembangan Arkeologi Nasional.

Rizaldy, M. F. G, Suryawan, I. B. (2019). Studi Daya Dukung Fisik Wisata Bahari USAT Liberty Wreck di Desa Tulamben Bali. Jurnal Destinasi Pariwisata, 7(1), 163-167.

Ross, S., \& Wall, G. (1999). Ecotourism: towards congruence between theory and practice, Tourism Management, 20(1), 123-132.

Sosmiarti, S., \& Fahlefi, U. A. (2019). Kearifan Lokal Masyarakat Soasio melalui Program Paket Wisata dan Rumah Budaya sebagai Pusat Kesultanan Tidore. Buletin Ilmiah Nagari Membangun, 2(2), 94-108.

Wisha, U. J., \& Heriati, A. (2016). Analisis Julat Pasang Surut (Tidal Range) dan Pengaruhnya Terhadap Sebaran Total Sedimen Tersuspensi (TSS) di Perairan Teluk Pare. Jurnal Kelautan. 9(1), 23-31.

Wisha, U. J., Gemilang, W. A., Rahmawan, G. A., \& Kusumah, G. (2017). Pola Sebaran Sedimen Dasar Berdasarkan Karakteristik Morfologi dan Hidro-Oseanografi Menggunakan Model Interpolasi dan Simulasi Numerik di Perairan
Utara Pulau Simeuluecut. Jurnal Kelautan: Indonesian Journal of Marine Science and Technology, 10(1), 29-40.

Wulandary, S. Y., Yusuf, M., \& Muslim. (2014). Kajian Konsentrasi dan Sebaran Parameter Kualitas Air di Perairan Pantai Genuk, Semarang. Bull. Ose. Mar. 3(1), 9-19.

Yusmaini, E. (2012-2013). Panduan Pengenalan Keramik. Modul khusus pembelajaran keramik. Jakarta: Pusat Arkeologi Nasional. Tidak diterbitkan.

Zulfari, M. Hasbiansyah. (2015). Kapal Karam USAT Liberty Bali: Pilot Projek Underwater Museum di Indonesia. Yogyakarta: Progam Kreativitas Mahasiswa 
